\title{
A review of progress and opportunities to foster development of sustainability-related competencies in engineering education
}

\author{
Cheryl Desha, School of Engineering and Built Environment, Griffith University, Australia \\ c.desha@griffith.edu.au, https://www.linkedin.com/in/cheryl-desha-898009b, OrcID: 0000-0002-4026-0830
}

Debra Rowe, Professor, Sustainable Energy and Social Sciences, Oakland Community College, USA/ President US Partnership for Education for Sustainable Development debrarowe@aya.yale.edu, https://www.linkedin.com/in/debra-rowe-589bb65/

Doug Hargreaves, Professor Emeritus, Queensland University of Technology, Australia d.hargreaves@qut.edu.au, https://www.linkedin.com/in/doug-hargreaves-am-1b6616a/?originalSubdomain=au

\begin{abstract}
Over the last decade and prompted by the United Nations (UN) 2030 Framework, significant engineering bodies have been calling for education directed towards achieving the UN Sustainable Development Goals (SDGs). In this paper, the authors reflect on progress to enable SDG knowledge and skills in engineering studies, overviewing key examples of efforts within the global professional engineering and education community, including Australia and the United States of America (the US). Acknowledging differences in language and guidance around the world, the authors discuss the need to provide clear and concise language regarding: 1) statements for desirable graduate attributes, 2) required knowledge and skill (i.e. competency) development, and 3) commentary/ guiding elements and indicators. The paper concludes with recommending accreditation bodies and professional societies and colleges make use of current international review processes underway by the International Engineering Alliance (IEA) and the World Federation of Engineering Organisations (WFEO), to update accreditation and supporting documents to ensure graduates have capacity to deliver solutions for 'thriving humanity and planet' in the $21^{\text {st }}$ Century. The authors also challenge educators to review and renew their institution's desired graduate attributes and program offerings to ensure curriculum develops capacity for achieving the UN SDG goals, targets and indicators.
\end{abstract}

KEY WORDS: sustainability competencies, United Nations Sustainable Development Goals, competencies, knowledge and skills, accreditation, rapid curriculum renewal

\section{INTRODUCTION}

For more than two decades, in collaboration with our mentors and colleagues, we have been advocating for and actioning systemic change in embedding education for sustainability within our engineering programs, to produce engineers who can make a positive difference - for people, planet and prosperity (for example Rowe 2007 in Science, and Desha and Hargroves 2011). Within the span of the authors' careers the transition to education for sustainble development has at times felt lengthy, and yet in the context of the 200-year journey since industrialisation, it has at least been visible, measurable and with substantial progress made in some parts of the world (Thurer et al. 2017).

In recent years signficant forums have been convened on the topic, including for example the International Forum on Engineering Capacity, hosted by the China Association of Science and Technology (see for example Brijmohan (2018) on the call for action, and Taylor (2018) on the topic of engaging with the International Engineering Alliance Accords). In 2020 the extent of progress documented by Byrne et al. for the same conference in 2010 (Byrne et al., 2010, 2013) will be discussed at the $10^{\text {th }}$ "Engineering Education for Sustainable Development" conference in Ireland. The 2019 World Federation of Engineering Organisations (WFEO) World Engineers Convention (WEC) theme "Engineering a Sustainable World: The next 100 years" and location (Melbourne) also creates an historic moment in the global race for sustainable engineering, alongside Engineers 
Australia's celebration of its centenary.

Clearly engineers remain a critical piece of the puzzle in creating built environments conducive to life in the $21^{\text {st }}$ Century (Mulder et al. 2013, Rowe 2014, Crosthwaite, 2019). Not only are we called on as technological pioneers of wonders such as artificial intelligence, quantum computing, the internet of things, geospatial digitalisation and communication, we are also required to be planetary stewards in advancing the 2030 goals of sustainable development, as outlined in the 17 United Nations Sustainable Development Goals or 'SDGs' (United Nations, 2015). Far from the engineering workplace in the $20^{\text {th }}$ Century, today's digital, automated and real-time connected complex engineering work places demand new knowledge and skills to practice. In addition, vastly improved knowledge regarding environmental and social consequences of design, construction and operational decisions require the development of distinct knowledge and skills for solutions that restore and reinvigorate our urban, rural, atmospheric and ocean environments (Desha et al. 2009; Thürer et al., 2017).

Within this context, in this paper we comment on significant global efforts to date, and next steps underway, to 'deepen' the integration of sustainability into engineering curriculum. This involves building on an appreciation of complexity, whole system thinking, and expanding viewpoints on design considerations, to apply tangible and essential sustainability knowledge and skills that advance the SDGs and maintain the habitability of the planet while improving quality of life globally, all in the context of significant environmental and other disruptions. Beginning with an overview of key international organisations and competencies-related activities regarding sustainable development, we highlight the reach of requirements and guidance, and precedents for progress. We draw on lived experiences and education research in the academic sector, including in Australia and the United States of America (the US), to highlight opportunities to progress. This spans diversity and inclusion within social well-being considerations, in addition to often-cited environmental and ethical considerations (see for example Svanström et al., 2008; Segalas et al., 2009; Wiek et al., 2011; Lönngren and Svanström, 2015; Guerra, 2018; Mukhtar et al., 2019). The paper concludes with several recommendations for next steps with regard to implications for accreditation standards, professional society contributions, as well as institutions' curricula renewal, and leverage points and opportunities for immediate action to develop graduates that have the capacity to deliver on global expectations for life in the $21^{\text {st }}$ Century.

\section{SUSTAINABILITY COMPETENCIES - PROGRESS TO DATE}

Reflecting on competencies (i.e. knowledge and skills) for sustainable development is a challenging and complex activity, connected inextricably with a complicated web of language, terminology at the intersection of how and what we teach students as they journey through their engineering progam of study. Indeed, much of the literature in education for sustainable development over the last twenty years has been attempting to find the elusive formula to engage students in sustainability-related knowledge and skill development through innovation in ways of teaching as much as innovation about what is being taught. In the following paragraphs we consider the progress made to date by key world bodies and two national bodies - Australia and the US - to guide such activities through the use of tools including standards, codes of practice, bodies of knowledge and commentaries, acknowledging similarities and differences between terms and meanings. We use these insights to discuss opportunities for deepening sustainability-related competencies going forward. The UN SDGs and other international compacts have also prompted action but are not detailed here.

\subsection{Key context: world bodies}

In commencing this discussion, it is important to provide a common platform of knowledge around the key organisations and terminology used regarding the attainment of knowledge and skills relevant to sustainability outcomes. In this paper we refer to competencies (i.e. knowledge and skills) being developed to produce graduates with desireable 'attributes'. Variability in evaluating process and the descriptors used for key competencies exist between different countries, even within the membership of bodies such as the World Federation of Engineering Organisations (WFEO) and the International 
Engineering Alliance (IEA) - these are noted in the discussion of Country level examples that follow.

\subsubsection{International Engineering Alliance (IEA)}

The IEA is a global not-for-profit organisation across seven multilateral engineering accords and agreements relating to engineering education and professional competence/registration/licensure quality assurance and mobility. In 2013 the IEA developed the IEA Graduate Attributes and Professional Competencies Standards (IEA, 2013) as international engineering benchmark standards. These standards provide an essential platform for dialogue between national accreditation and chartered/registration bodies, enabling common understanding of expectations about what should be part of an engineer's repertoir. This includes three international agreements for engineering programs (Washington Accord), engineering technology programs (Sydney Accord) and engineering technician programs (Dublin Accord).

Currently sustainability is incorporated into curricula of programs accredited under these accords, via three 'knowledge', 'graduate' and 'professional competency' profiles, illustrated here with respect to sustainability, under the Washington Accord (IEA, 2013):

- 'Knowledge Profiles':WK7 - Comprehension of the role of engineering in society and identified issues in engineering practice in the discipline: ethics and the professional responsibility of an engineer to public safety; the impacts of engineering activity: economic, social, cultural, environmental and sustainability

- 'Graduate Attribute': WA7 - Environment and Sustainability: Type of solutions. solutions. Understand and evaluate the sustainability and impact of professional engineering work in the solution of complex engineering problems in societal and environmental contexts (WK7).

- 'Professional Competency': EC6 - Protection of society: Types of activity and responsibility to public. Recognise the reasonably foreseeable social, cultural and environmental effects of complex activities generally, and have regard to the need for sustainability; recognise that the protection of society is the highest priority.

\subsubsection{World Federation of Engineering Organisations (WFEO)}

Representing nearly 100 nations and 30 million engineers, WFEO is the peak body for professional engineering institutions. Led by President Dr Marlene Kanga (also past President, Engineers Australia), the organisation is focused on advancing the UN SDGs, including achieving zero hunger, sustainable cities, and clean water and sanitation. Amongst other aspirations WFEO aims, "To foster socio-economic security and sustainable development and poverty alleviation among all countries of the world, through the proper application of technology" (WFEO 2018).

In 2013, WFEO produced a Model Code of Practice for Sustainable Development and Environmental Stewardship, including an Interpretive Guide (WFEO, 2013). In 2015, WFEO signed a Cooperation agreement with the IEA (following an earlier Memorandum of Understanding) to enable mulilateral systems of accreditation and evaluation of professional competence globally. The agreement also enables dialogue between the organisations regarding the standards and their composition.

As noted by WFEO Vice president and Chair of Capacity Building Committee, Professor Yashin Brijmohan, there is still inconsistency in the quality of graduates from around the world, which requires urgent attention from WFEO and other organisations (Brijmohan 2018). He further highlighted the importance of understanding complexity and valuing and leveraging diversity. Addressing this inconsistency, in its WFEO Engineering 2030 Plan, the second of 10 Principles states, "Ensure appropriate standards in engineering education - which address current and future needs of industry and society including teaching approaches (pedagogy), the use of technology and graduate outcomes" (WFEO, 2018).

The following bullet points highlight several WFEO related events and committees that have made significant progress over recent years, in creating a conversation about how to move forward:

- 2018 International Forum on Engineering Capacity (Beijing, China) - (WFEO, Chinese Academy 
of Science and Technology - CAST, and the Federation of Engineering Institutions of Asia and Pacific - FEIAP) Discussing the need for the best engineering education standards that reflect the changes in technology and expectations for engineering graduates in the future - Key strategic priority as part of the WFEO Engineering 2030 Plan.

- Committee on Engineering Education (CEIE) - To work for the development of the profession and the review of the engineering programs through collaboration with different educational establishments and organizations; Biennial conference on engineering education and publication of IDEAS journal.

- Committee on Engineering and the Environment (CEE) - Codes of Practice for Sustainable Development and Environmental Stewardship for Engineers; Principles of Climate Change Adaptation for Engineers; Participation in the UN Conference of Parties (CoP) events on engineering approaches to climate change mitigation and adaptation.

- World Engineering Day for Sustainable Development - The UNESCO Executive Board adopted a draft decision on 17 April 2019 in plenary session, recommending that the General Conference in November 2019 "decide to proclaim 4 March of every year World Engineering Day for Sustainable Development".

WFEO has also been in many small and large initiatives to embed sustainability within engineering curriculum, including hosting the Committee on Education In Engineering in 2016.

\subsection{Country-level examples: Australia and the US}

Around the world, engineering competency standards have been responding to the context provided above, with updates to integrate 'sustainability' considerations into engineering curriculum. Covering all variations is beyond the scope of this paper. Instead we focused on observing the similarities and differences in the Australian and US experiences, to reach the level of comprehensive sustainability integration necessary for a sustainable future. We summarise these aspects and discuss opportunities for further advancing competency and accreditation standards, prompted by consdering the context of these two countries.

\subsubsection{EA (Australia)}

For the last year the Australian Council of Engineering Deans (ACED) has been undertaking the 2035 Engineering Attributes Initiative (Crosthwaite, 2019), which is exploring the knowledge, skills and attributes of professional engineers required to meet anticipated changes in the nature of engineering work in Australia in the year 2035. In Australia, the Engineers Australia Competency Standard, which is consistent with those used by the International Engineering Alliance (2013), the organisation refers to engineering Graduate capabilites being developed through focusing on Competencies and Elements of Competency (Engineers Australia, 2011). Each Element of Competency has a number of suggested Indicators of Attainment as summarised within Figure 1 for the Stage 1 Competency Standard (for undergraduate curriculum).

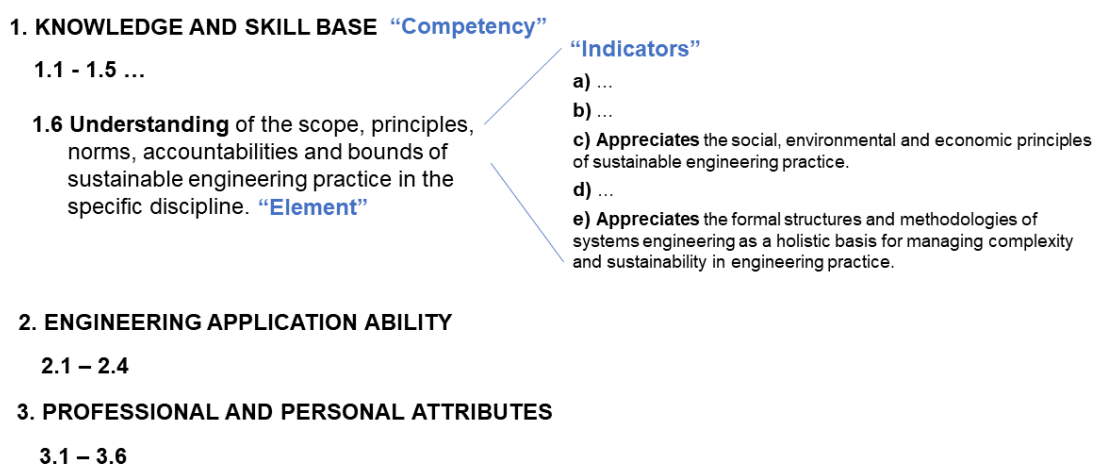


Figure 1. Illustration of language within the Engineers Australia Competency Standard Source: Adapted from (EA, 2011)

While the standards note that these are not comprehensive sub-lists, they do provide insight to the breadth and depth of ability expected, informing curriculum design and assisting in knowing how to demonstrate the competency. The Indicators of Attainment are not prescriptive, but do serve as guides to checking the meaning and scope of each of the Elements. With reference to the WFEO model code of practice for sustainable development and environmental stewardship, there is still more that can be done to improve the indicators, to guide Australian educators in fulfilling the potential of the three competencies and their elements of competency.

In the meantime, innovative industry-based engineering education initiatives are being pioneered at Swinburne University of Technology through its engineering practice academy and Charles Sturt University through its engineering department. In addition, private providers such as Engineers Without Borders and Project Everest Ventures are being established to cater directly to university needs for interdisciplinary and community-engaged curriculum in Australia and overseas, which span first-year through to final year sustainability-related competency development in social enterprise and end-user empathetic design, for more than 10,000 engineering students each year. Work from these initiatives could also contribute to building the next renewal of Australia's accreditation criteria.

\subsubsection{ABET (US)}

In the US, ABET (previously called Accreditation Board for Engineering and Technology) accredits over 4,000 programs at 793 colleges and universities in 32 countries, including the US (ABET, 2018). A set of 'program criteria' is provided by ABET for all accredited engineering programs, related to 'student outcomes', wherein the relevant 'Lead Society' assists with accreditation.In the ABET accreditations, used for bachelors and masters engineering degree programs, Criterion 3 addresses student learning outcomes, and specifically includes, "an ability to apply engineering design to produce solutions that meet specified needs with consideration of public health, safety, and welfare, as well as global, cultural, social, environmental, and economic factors" and "ethical and professional responsibilities... which must consider the impact of engineering solutions in global, economic, environmental, and societal contexts" (ABET, n.d.). However, these outcome statements do not specifically describe the needed competencies, attributes, elements and indicators of attainment to address the sustainable development goals or even sustainable development in general. They only address the need to include economic, environmental and social and ethical factors in design solutions.

Each discipline of engineering has additional criteria and the connection to sustainable development varies. While civil engineering and its lead society, the American Society of Civil Engineers (ASCE), specifically requires programs to "include principles of sustainability in design", and architectural engineering requires each student "Considers fundamental attributes of building performance and sustainability", other programs and their professional societies (e.g. manufacturing and mechanical engineering programs) have no mention of sustainable development considerations in the criteria even though their impacts on the world could be quite damaging if sustainable principles are not used (ASCE, 2019a; 2019b).

ASCE is a leader in that it has created a Body of Knowledge, in its third edition, that includes a section on sustainability, providing definitions, and lists of both cognitive and afffective outcomes necessary for quality sustainability education (ASCE, 2017). The affective component is particularly important to build the self-concept and the dedication of the engineering graduate to include sustainability in their career. ASCE has also demonstrated leadership by creating a Commentary on the ABET accreditation program criteria (IEA, 2019) that helps evaluators and educators make the connections between the Body of Knowledge and the accreditation expectations.

Other engineering educators, in collaboration with professional engineering societies and/or convenings of professional engineers, would benefit from producing similar documents to those produced by ASCE. All areas of engineering areas would benefit from following the lead of ASCE to create a both a Body of Knowledge related to Sustainable Development and a Commentary on how it 
relates to accreditation. This should include the additional step of connecting their bodies of knowledge and commentaries on the accreditation program criteria to the UN Sustainable Development Goals' Targets.

\section{OPPORTUNITIES FOR DEEPENING SUSTAINABILITY RELATED COMPETENCIES}

As illustrated in Figure 2, there are significant opportunities for the IEA Accords to contribute to a global transformation of engineering practice towards sustainable development. This involves using and augmenting - the current standards to drive sustainability, and then harnessing the power of mobility and life-long learning to build capacity for delivering sustainable solutions throughout the spectrum of engineering infrastructure, products and services.

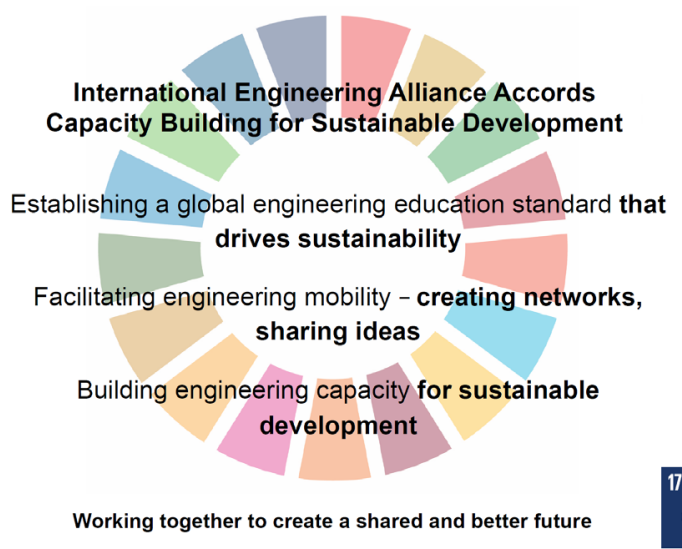

Figure 2 Forward-facing challenge for the IEA Accords, within the context of the UN SDGs (particularly Goal 17 Partnerships)

Source: Taylor (2018, p37)

Figure 3 below highlights the opportunity for deepening sustainability related competencies to enhance the engineering knowledge and skills development pathway following graduation from high school through the degrees and throughout the career. Building upon the image presented by Brijmohan (2018), the augmented figure highlights the embedded competencies in the attainment of qualifications through an engineering professional's career. 


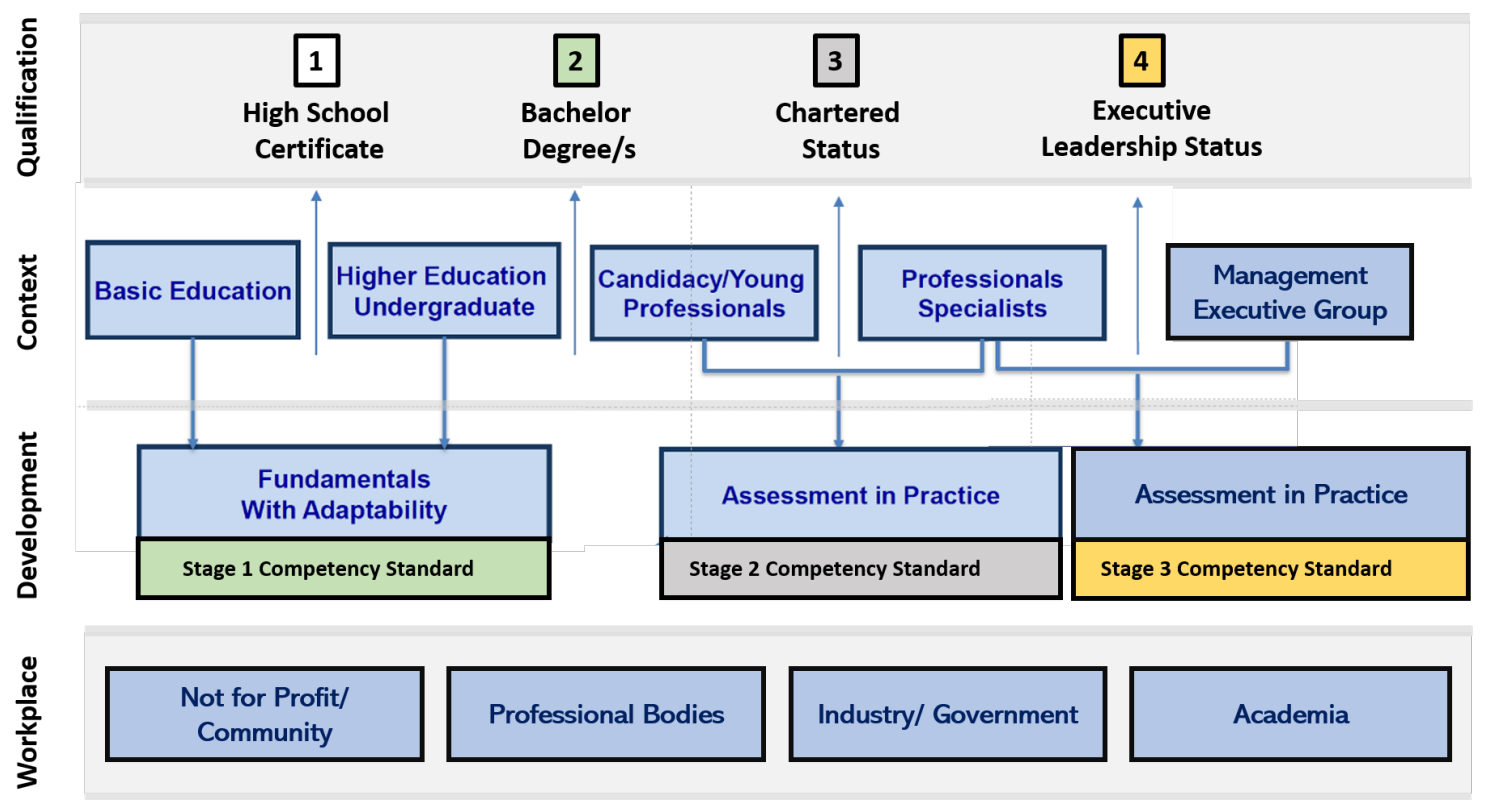

Figure 3. The capacity building pipeline for engineering, in the context of competency standards Source: Adapted from Brijmohan (2018)

Considering the rigorous and progressive nature of the competency standards, the strategic embedding of tangible and meaningful sustainability competencies, elements and indicators will have direct impact on the upskilling of engineering professionals in these areas. Essentially the competency standards enable the institutionalizing of sustainable development related expectations for engineering practice and performance. It can only be beneficial in this regard, to deepen educators' and professionals' understanding of the learning outcomes and competencies required at each level, which is necessary to build the capacity and professionalism of sustainable development within engineering. Education global standards should consider both the students' and the professionals' potential future real impacts on societies through their practices.

\subsection{Harnessing other Higher Education Sector efforts}

A number of signficant education for sustainability initiatives have been underway in the Higher Education Sector over the last decade in particular, as indicated in Table 1 below. These initiatives have been varied in their attention to engineering as a discipline, but regardless have contributed awareness and appreciation of the variety and extent of knowledge and skill sets that are related to delivering 'sustainability outcomes' in projects.

\begin{tabular}{|l|c|}
\hline Higher Education Sector Initiatives and Brief Description (in alphabetical order) & Country/ Region \\
\hline \hline $\begin{array}{l}\text { Alliance for Sustainability Leadership in Education (EAUC) } \\
\begin{array}{l}\text { Leading and empowering the post-16 education sector to make sustainability 'just good } \\
\text { business'. }\end{array}\end{array}$ & UK \\
$\begin{array}{l}\text { Global Alliance } \\
\text { International informal alliance of higher education sustainable development national } \\
\text { and regional networks, underpinned by the SDG Accord - a collective response to the } \\
\text { Global Goals by the University and College sector globally - created in collaboration } \\
\text { with the UN Higher Education Sustainability Initiative (HESI). }\end{array}$ & International \\
\hline $\begin{array}{l}\text { Copernicus Alliance } \\
\text { Launched in 1993, based on a charter for Universities to sign as a self-commitment to }\end{array}$ & Europe \\
\hline
\end{tabular}




\begin{tabular}{|c|c|}
\hline Education Sector Initiatives and Brief Description (in alphabetical or & Country/ Region \\
\hline fol & \\
\hline $\begin{array}{l}\text { Higher Education Academy - Education for Sustainable Development Knowledge } \\
\text { Hub } \\
\text { Includes the Future Fit Framework (2012) to raise awareness amongst educators, and the } \\
\text { ESD tutor resource and student activity series to help incorporate ESD into teaching. }\end{array}$ & UK \\
\hline $\begin{array}{l}\text { Principles for Responsible Management Education (PRME) } \\
\text { UN supported initiative to raise the profile of sustainability in schools globally, particularly } \\
\text { in business and management-related higher education programs. }\end{array}$ & Global \\
\hline $\begin{array}{l}\text { ProSPER.Net } \\
\text { Promotion of Sustainability in postgraduate education and research }\end{array}$ & $\begin{array}{c}\text { Japan/ } \\
\text { Asia Pacific }\end{array}$ \\
\hline $\begin{array}{l}\text { Sulitest } \\
\text { Includes learning tools and assessments used in over } 55 \text { countries to expand sustainable } \\
\text { development knowledge, skills, and mindset that motivates individuals to become deeply } \\
\text { committed to build a sustainable future and to make informed and effective decisions. } \\
\text { Sustainable Development Solutions Network } \\
\begin{array}{l}\text { Promotes integrated approaches to implement the Sustainable Development Goals (SDGs) } \\
\text { and the Paris Agreement on Climate Change, through education, research, policy analysis, } \\
\text { and global cooperation. }\end{array}\end{array}$ & $\begin{array}{c}\text { Many UN } \\
\text { connections and } \\
\text { higher education } \\
\text { multi-country } \\
\text { networks }\end{array}$ \\
\hline $\begin{array}{l}\text { Sustainability Education and Economic Development (SEED) Center } \\
\text { Advancing sustainability and clean technology education programs at colleges by sharing } \\
\text { innovative practices and materials to help college administrators, faculty, and staff build the } \\
\text { green and more sustainable economy. } \\
\text { Sustainability Improves Student Learning } \\
\text { A US Department of Education suppported project developed by a select group of STEM } \\
\text { academic associations, including the American Society for Engineering Education, working } \\
\text { together to better prepare undergraduate students for the } 21 \text { st-century "Big Questions" that } \\
\text { relate to real-world challenges such as energy, air and water quality, and climate change }\end{array}$ & US \\
\hline $\begin{array}{l}\text { United Nations Higher Education Sustainability Initiative (HESI) } \\
\text { Provides higher education institutions with a unique interface between higher education, } \\
\text { science, and policy making. A partnership between United Nations Department of Economic } \\
\text { and Social Affairs, UNESCO, United Nations Environment, UN Global Compact's } \\
\text { Principles for Responsible Management Education (PRME) initiative, United Nations } \\
\text { University (UNU), UN-HABITAT, UNCTAD and UNITAR. The Higher Education } \\
\text { Sustainability Initiative is supported by a range of higher education international networks, } \\
\text { national and regional organizations, and several student organizations. }\end{array}$ & $\begin{array}{c}\text { International } \\
\text { (United Nations) }\end{array}$ \\
\hline 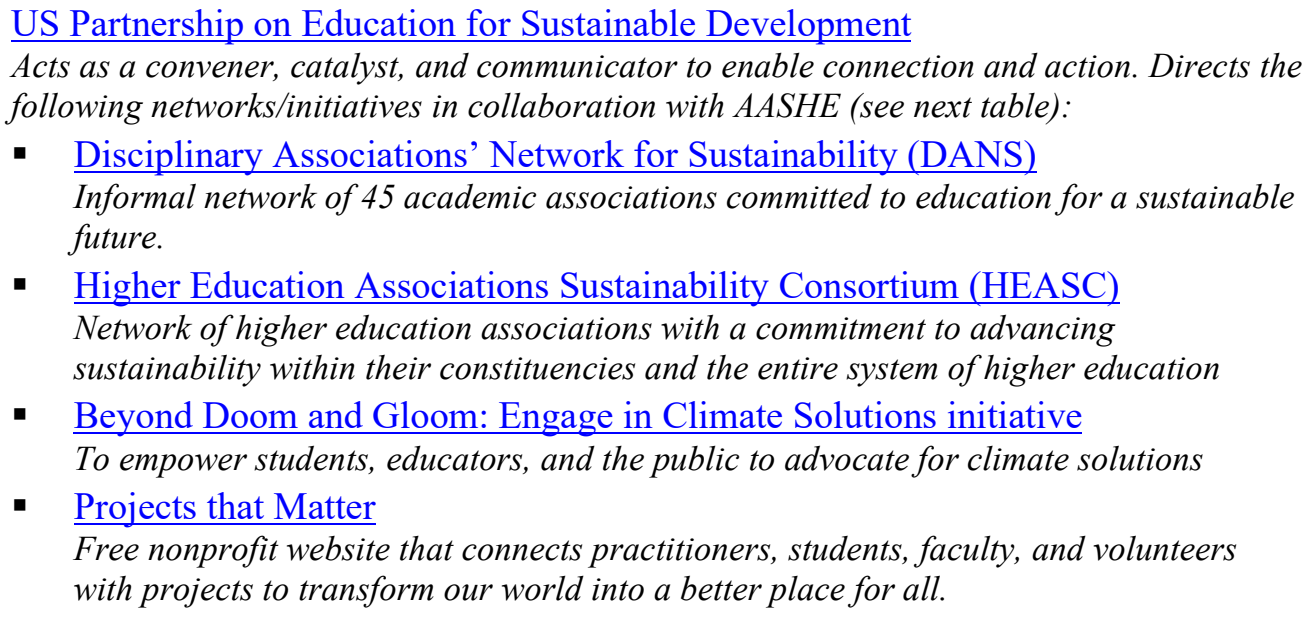 & US \\
\hline
\end{tabular}




\section{Table 1. Sample of key higher education sector initiatives that intersect with engineering efforts regarding sustainable development competencies}

In addition to direct efforts by academic colleagues and teaching and learning institutions within the Higher Education sector, there has also been a significant effort by campus managers - and academics working with campus managers - internationally, to raise awareness about what is possible. This includes addressing the social and environmental impacts of operating the campuses themselves, in addition to living lab campus and community initiatives where building and facilities projects are connected directly to curriculum.

Table 2 provides a snapshot of examples internationally where these initiatives have become wellknown (for a list of 45 such groups internationally, see The Green Office Movement, n.d.). This has been assisted through the United Nations Environmental Education and Training Unit (EETU). Universities are also working with the newly renamed UN Environment's Youth and Education Alliance (previously Global Universities Partnership-GUPES) to develop and implement national and regional Green University Networks. The International Sustainable Campus Network (ISCN) is a nonprofit association of globally leading colleges and universities representing over 20 countries and working together to holistically integrate sustainability into campus operations, research and teaching.

\begin{tabular}{|l|l|}
\hline Higher Education Sector Initiative and Brief Description (in alphabetical order) & \multicolumn{1}{|c|}{ Country } \\
\hline \hline ACTS (Australian Campuses Towards Sustainability) & Australia \\
\hline Association for the Advancement of Sustainability in Higher Education (AASHE) & $\begin{array}{l}\text { US and } \\
\text { international }\end{array}$ \\
\hline $\begin{array}{l}\text { ARIUSA (Alianza de Redes Iberoamericanas de Universidades por la Sustentabilidad } \\
\text { y el Ambiente) }\end{array}$ & South America \\
\hline$\underline{\text { Campus Responables }}$ & France \\
\hline$\underline{\text { CAS-Net JAPAN (Campus Sustainability Network in Japan) }}$ & Japan \\
\hline$\underline{\text { KAGCI (Korean Association for Green Campus Initiative) }}$ & Korea \\
\hline Thailand Sustainable University Network & Thailand \\
\hline
\end{tabular}

Table 2. Sample of national campus-based networks that raise awareness via modeling sustainability

\subsection{Connecting industry within the curriculum}

A number of researchers have identified the criticality of collaborating with industry to ensure sustainability is well-integrated within engineering curriculum (Rowe 2007; Male et al. 2016). Not only do industry provide a direct check-in with regard to current and emergent specific - and priority - knowledge and skill needs, they can also provide ready-access to onsite and in-field experiences with engineering mentors, to enhance the desired competency development.

International declarations and academic papers on sustainable development competencies have emphasized the need to help students develop the change-agent identity and skills to include sustainable development in norms and practices in their careers within the business, government, nonprofit and educational sectors. Key components of the curricula include real-world problem-solving projects that come from working with industry and community organizations, combined with student reflections on building a change-agent self-concept and utilizing competencies assessment for continuous feedback and improvement (Svanstrom et al. 2007, Sustainability Improves Student Learning 2012). It takes effort to build the ongoing partnerships with industry, government and nonprofits that provide real-world problem-solving opportunities to students.

Some universities have stepped up to the opportunity to be a transformational engine to deliver on the SDGs Purcell et al (2019). While these tools and champion examples are helpful, a more systematic response from the professional engineering societies, in partnership with industries and governments, 
would create a more institutionalized, ongoing change in curricula needed for the graduates of the future.

\subsection{Competency review and renewal}

The journey of competency articulation in relation to sustainable development has been well documented, from the early discussions by researchers such as Crofton (2000) and with regard to ethics and practice-focused curriculum that extend to include sustainability (Johnston et al. 2000), through to case study evaluations at a national level (for example Segalas et al. 2009), considering the implications of international mobility (Campbel et al. 2009), energy and population policy (Hargreaves 2010, 2011), and opportunities to learn from community leadership models (Rowe and Hiser 2015). A detailed summary of progress was also developed in consultation with colleagues globally, as part of a conference on Engineering Education for Sustainable Development hosted by Corke University in 2010 (Byrne et al. 2010; 2013).

More recently researchers have been attempting to 'deepen' statements relating to competencies, elements, indicators and learning outcomes, across a range of topic areas. Of note is the work by Lonngren and Svanstrom (2015) who used a consultation approach to identify 11 priority learning outcomes to embed in curriculum that addresses 'wicked sustainability problems' (i.e. problems that are highly complex, contested and which lack definite solutions).

\subsection{Addressing paradigms of teaching in engineering education}

Examples of curriculum renewal in relation to sustainable development have been documented in numerous individual case study accounts of personal experiences in coursework development, program renewal and pilot projects (Thürer et al., 2017), and in the potential for partnerships to foster shifts in practice (Rowe and Hiser, 2015). The Center for Sustainable Engineering offers workshops, a US-based benchmarking and resources to "enhance education around the world in sustainable engineering". A deep exploration of the process for rapid engineering curriculum renewal towards sustainable development has also been documented (see Desha and Hargroves, 2011), with the creation of a model and a series of steps to take to ensure holistic and timely curriculum renewal.

Researchers such as McAuliffe et al. (2009) have highlighted the challenges in teaching contexts where students may be of differing ages, demographic and socio-economic background, where teaching often then reverts to teacher-centered learning (pedagogy). Considering the variety of alternative teaching methodologies encouraged to develop sustainability related knowledge and skills, this has been a challenge to address, with early and ongoing efforts by Svanström et al. (2008) and Rowe and Johnston (2013) around defining learning outcomes for sustainable development, work by Lozano et al. (2017) to connect competencies and pedagogical approaches, and the ASCE's codification efforts (2018).

One international initiative is attempting to use an existing 'holistic' teaching methodology around CDIO (Conceive, Design, Implement, Operate), to integrate the development of sustainability related knowledge and skills (see for example Hussmann et al. 2010, and Desha and Dawes, 2013). A STEM based initiative, "Sustainability Improves Student Learning", funded by the US National Science Foundation emphasizes the essential components of quality sustainablity assignments, with an emphsis on empowering and educating students through a focus on solutions and real world problem based learning (https://serc.carleton.edu/sisl/pedagogies.html) The initiative also includes helping students reflect on skills needed so they can create systems change within organizations and the larger society.

There are also plenty of examples of process inovation. We reference efforts to undertake joint development of open-source modular curriculum (Desha et al. 2013), work by Hargreaves (2016) on the use of large classes to engage first-years in a Professional Practice and Sustainability course, Rose et al. (2015) regarding the development of an online portal for first-year students to access sustainability content, Weatherton et al. (2015) who describe a multipronged approach for incorporating knowledge and skills withi civil undergraduate curriculum, and within the CDIO community (Conceive-Design-Implement-Operate), the discussion of structured inclusion of the 
UNESCO key competencies by Rosén et al. (2019), and 'green challenges' by Hussmann et al. (2010). Strategies have also been discussed more broadly with regard to how to inculcate sustainability in the curriculum (see for example Holgaard et al, 2016; and Kolmos et al. 2016).

\section{NEXT STEPS FOR GLOBAL PROGRESS}

This paper has looked across initiatives with curriculum development, and initiatives with overarching standards development, where work is being done to articulate the specifics of what is needed in engineering graduates - across and within disciplines - to achieve the unprecedented challenges set by both the UN SDGs and the threats to ecosystems' health necessary for sustaining human life.

In this paper we have provided an updated narrative on the winding journey of the engineering curriculum towards education for sustainable development, including the renewal of the underpinning competency standards. It is beyond the scope of this paper to suggest what the critical competencies, attributes, elements and indicators should be. That needs to be addressed in a process that engages the international organizations (the backbone of support) and the engineering societies (communities of practice) to: agree on overarching competencies for all engineers, and have each professional engineering society develop the specifics for their field. We have included the description and encouragement of this process (by us and champions in this area).

It is important to note that, since global standards should consider the real impact on societies, there is a need for both a more comprehensive inclusion of overarching sustainable development learning outcomes across engineering programs (e.g. designing for a circular economy, using the precautionary principle in design) and a deepening of sustainable development learning outcomes within each area of engineering, so all our graduates are prepared to create the solutions required in this sustainability challenged world. Within the last several years in particular, there have been significant calls to action globally, for engineers to embrace sustainable development practices, as highlighted in the following paragraphs.

\subsection{International organisations (world bodies) as the backbone of support}

In WFEO's Engineering 2030 Plan (2018), there are two projects underway with direct potential implications for standards review and renewal, namely:

- Reviewing and Developing Standards for Engineering Education to meet current and future needs of industry and society (Addressing SDG 4: Quality Education)

- Capacity Building for Engineering Education Systems, accreditation and registration to meet the needs for engineers around the world (Addressing SDG 4: Quality Education)

Detailed reports on committee activities on advancing the UN Sustainable Development Goals (UN SDGs) will be presented as part of the WFEO Biennial Report for the WFEO General Assembly in November 2019 and the $2^{\text {nd }}$ UNESCO Engineering Report is currently being prepared on a similar timeline.

UNESCO, WFEO and IEA have committed to work together, aligning with the UN SDGs and recognising the critical role of engineering to achieve the goals. At the June 2019 IEA Meeting in Hong Kong IEA delegates and representatives from UNESCO, WFEO, the International Federation of Engineering Education Societies (IFEES), Federation of Engineering Institutions of Asia and the Pacific (FEIAP), Federation of African Engineering Organisations (FAEO), European Network for Accreditation of Engineering Education (ENAEE) and UNESCO International Centre for Engineering Education (ICEE) participated in two workshops focused on the IEA Standards and Capacity Building. One key outcome was the establishment of an IEA/WFEO working group to review the IEA standards to ensure that they reflect contemporary values and employer needs as well as equip engineering professionals of the future to incorporate practices that advance the UN SDGs. A second key outcome was the creation of a working group to consider capacity building to increase the global reach of the IEA Agreements and Accords through capacity building efforts such as mentoring and training.

The International Engineering Alliance seeks to improve engineering education and competence 
globally through widening the recognition and uptake of its constituent Accords and Agreements. The Governing Group of the IEA may allocate resources to promote to potential constituents and provide information to other relevant international or national organisations. Thus the IEA have a mission to increase capacity either directly through membership of the Accords or acting as advisors to develop bodies to accredit engineering programmes and appropriate engineering education systems.

\subsection{Critical tasks for all stakeholders}

Looking ahead, we encourage a combination of world bodies, engineering educators and professional societies to follow the model of ASCE, supplementing accreditation criteria with bodies of knowledge and comments on the accreditation criteria. We further encourage engineering colleges and professional societies to map their work to all of the SDGs as well since we have not seen an international trend in this direction yet. We propose several critical next steps with regard to concrete actions for strengthening the accreditation requirements, strengthening institutional performance, and strengthening the community of practice:

\section{Include substantive sustainable development indicators/outcomes for each Competency Element}

Accreditation organisations develop their standards to different levels of details. Review the current list of indicators/outcomes for each competency element, and map a systematic array of sustainable development expected outcomes that provides a holistic guide for academics undertaking curriculum renewal, beyond the current somewhat ad hoc list that has evolved from incremental updates.

In the limited space available, we have not set out to create a specific list of indicators and refer the reader to ASCE's body of knowledge for examples. Instead we propose instead a process that academic engineering groups/societies could each create committees to develop the body of knowledge and relate it to the accreditation criteria, using ASCE's work as a model (see also Item 5). In all cases the engineering education community and the professional education community should be coming together to provide this level of detail. Both cognitive and affective outcomes should be addressed for quality sustainability education.

\section{Involve engineering academics and practitioners in the review and renewal process}

Sustainability champions pushed the production of ASCE's body of knowledge to include sustainablity and a document to connect it to accreditation. Future efforts need to depend less on small groups of sustainabiltiy champions and instead, be integrated as a norm into the professional bodies. Complementing the leadership work already undertaken by IEA, WFEO and national professional engineering agencies around the world and assuming those efforts will continue, a defined process to accomplish bodies of knowledge and connections to accreditation should be faciltiated. This body of knowledge development needs to include widespread engagement with engineers in the academic sector and in industry to facilitate a process that produces outcomes to ensure the proposed changes are sufficient for sustainable development, real world outcomes and to appropriately fit the changes within the curriculum structure practicalities faced by universities.

\section{Create a system of impact-accountability within the program accreditation process}

Building on the outcomes-based rigorous approach to accreditation already established within the IEA's accord documentation, implementing a training requirement for accreditation panel members that is appropriate to each country. This includes supporting the development of strong institutions for accreditation of engineering education and the development of accreditation bodies; and supporting the development of professional engineering institutions through capacity building efforts to support engineers' education and recognition of professional credentials. At the level of the educaiton institution it envolves ensuring that they have sufficient personal awareness of the sustainability knowledge and skills relevant to their disciplinary accreditation roles to know what to audit for in relation to sustainable development competencies in the curricula. This is critical with the rapid emergence of language, knowledge and skills, related to $21^{\text {st }}$ Century 
challenges and opportunities as discussed in the introduction.

\section{Develop and publish case studies on exemplar curricula that have embedded sustainability}

In order to move beyond ad hoc, champion-based curriculum renewal and life-long learning initiatives, it is imperative to learn from our successful - and unsuccessful attempts. Embracing the mindset of 'fail-fast - fail-safe', there is an urgent need for easy-access, deep-dive case studies to learn from, spanning curriculum and related assessments, to assist academics in knowing what they can achieve and how to go about it.

\section{Foster an international community of practice in engineering for sustainability}

With the scope of works created in the above-mentioned to-do list, it is imperative to sustain the energy, enthusiasm and commitment to this agenda over the next decade in particular. Behaviour change literature advises nothing short of a full-scale commitment to fostering a peer group - in this case a community of practice - for ensuring the implementation of the measures described. This could be potentially aligned with existing conferences as a standing item such as a forum, to provide visibility, clear signaling of priority, and the space for ideas and challenges to be regularly discussed and progressed.

To accomplish the five items above, professional engineering associations in collaboration with colleges of engineering around the world need to create active committees to accomplish the more specific definitions of sustainable development competencies, attributes and indicators (knowledge, skills and assessments) for each engineering program type (e.g. agriculture, manufacturing) and a joint committee across professional associations to create the shared and overarching sustainable development competencies for all engineering programs. Facilitators and communications efforts must be supported to help grow the international community of practice by these professional societies. Surveys of outstanding sustainable industries and SDG practitioners need to occur to collect the skills and indicators that will be most useful to the industry as well as the solving of the SDGs. Journal editors need to create special issues to publish the case studies. Repositories of curricular materials need to be created by the professional societies, and support from the accreditation agencies for the training of the accreditation visitors will be needed. The world asks nothing less of us than this. These propositions have been distilled from the authors' experiences within the sector, and through sense-checking with senior colleagues in the field. However, it is quite possible that we have omitted another critical step - or indeed missed the opportunity to highlight an important ingredient within these steps. We look forward to hearing from colleagues - and the readership - with regard to additional ideas, references, initiatives and opportunities, via the conference app and/or by email.

In conclusion, we are in a unique and important position to change the norms, standards and competencies within both the engineering professions and within engineering education to help assure a more sustainable future for present and future generations. The above recommendations, when implemented, will move us more responsibly and effectively to a sustainable future. We cannot afford to do any less.

\section{ACKNOWLEDGEMENTS}

The authors gratefully appreciate the time and comments provided by Emeritus Professor Doug Hargreaves AM, and Emeritus Professor Elizabeth Taylor AO, who have assisted in documenting and contextualising the various initiatives underway internationally with regard to engineering education for sustainable development. The first author is indebted to the efforts of colleagues in The Natural Edge Project who spent 10 years producing seven engineering textbooks and hundreds of hours of online curriculum on engineering education for sustainable development. The second author acknowledges the thousands of individuals who have played a part in transforming the engineering education system in the US and internationally, and who have supported her lifelong crusade for professionals who can deliver development that also enables our future generations' ability to thrive.

\section{REFERENCES}


ABET. 2018. "Criteria for accrediting engineering programs, 2018-2019.” Baltimore: ABET.

ASCE. "Civil Engineering Body of Knowledge: Preparing the Future Civil Engineer" ( $\left.3{ }^{\text {rd }} \mathrm{Ed}\right)$, prepared by the Civil Engineering Body of Knowledge 3 Task Committee, 2019a.

ASCE. "Commentary: on the ABET Program Criteria for Civil and Similarly Named Programs Effective for 2019-2020 Accreditation Cycle", January 2019b.

Brijmohan, J., "Building Engineering Capacity and Capability for the Evolving Technological Era: Policy, International Standards, and Regulation", in International Forum on Engineering Capacity: Capacity Building for a Shared and Better Future of Mankind, hosted by the China Association for Science and Technology (CAST), 5 December 2018.

Byrne, E., Desha, C., Fitzpatrick, J., and Hargroves, K., "Exploring sustainability themes in engineering accreditation and curricula", International Journal of Sustainability in Higher Education, 2013, 14(4), pp 384-403.

Byrne, E.P., Desha, C., Fitzpatrick, J.J. and Hargroves, K. 'Engineering Education for Sustainable Development: A Review of International Progress', workshop paper for the 3rd International Symposium for Engineering Education, Cork, 30 June - 2 July 2010.

Committee on Education In Engineering, World Federation of Engineering Organizations, Engineering Education for Sustainable Development, COMMITTEE ON EDUCATION IN ENGINEERING, Journal IDEAS No. 19, 2016 (19)

Crosthwaite, C., Engineering Futures 2035: A Scoping Study. Report to the Australian Council of Engineering Deans, April 2019.

Desha, C., and Dawes, L., "Building capacity for 21 st century engineering through curriculum renewal", In $9^{\text {th }}$ International CDIO Conference, Massachusetts Institute of Technology and Harvard University School of Engineering and Applied Sciences, 9-13 June 2013, Cambridge, Massachusetts.

Desha, C. and Hargroves, K., Higher Education and Sustainable Development: A Model for Curriculum Renewal, Taylor and Francis, London, 2011.

Desha, C., Hargroves, C., Dawes, L., and Hargreaves, D., "Collaborative resource development for energy efficiency education", in Lemckert, Charles \& Jenkins, Graham A. (Eds.) Proceedings of 24th Annual Austalasian Association of Engineering Education Conference, Griffith School of Engineering, Griffith University, Gold Coast, Queensland, Australia, 2013.

Desha, C., Hargroves, K., and Smith, M., "Addressing the time lag dilemma in curriculum renewal towards engineering education for sustainable development", International Journal of Sustainability in Higher Education, 2009, 10(2), pp 184-199.

Engineers Australia., "Competency Standard for Professional Engineer", extract from the Engineers Australia - Chartered Status Handbook, Canberra, 2017.

Engineers Australia, "National Generic Stage 1 Competency Standards - 2011”, Canberra, 2011.

Guerra, A., "Integration of Sustainability in Engineering Education", in International Journal of Sustainability in Higher Education, 2017, 18(3), pp 436-454.

Hargreaves, D., "Directed student engagement and learning in a large engineering unit", In $12^{\text {th }}$ International CDIO Conference, 12-16 June 2016, Turku, Finland.

Holgaard, J.E., Hadgraft, R.G, Kolmosa, A., and Guerra, A., "Strategies for education for sustainable development - Danish and Australian perspectives", in Journal of Cleaner Production, 2016, 112(4), pp3479-3491

Hussmann, P., Trandum, C. and Vigild, M., "How to Include Sustainability in Engineering Education: The "Green Challenge" at DTU is One Way", in $20106^{\text {th }}$ International CDIO Conference, École Polytechnique de Montréal, Canada. 
International Engineering Alliance (IEA), "Section 4 Common Range and Contextual Definitions of Graduate Attributes and Professional Competencies" in IEA Graduate Attributes and Professional Competences, Version 3: 21 June 2013.

Johnston, S., McGregor, H., and Taylor, E., "Practice-focused ethics in Australian engineering education", European Journal of Engineering Education, 2000, 25:4, 315-324,

Kolmos, A., Hadgraft, R.G., and Holgaard, J.E. "Response strategies for curriculum change in engineering", in International Journal of Technology and Design Education, 26(3), pp 391-411, 2016.

Lönngren, J. and Svanström, M., "Assessing 'Wicked Sustainability Problems' - Literacy in Engineering Education", in 122nd ASEE Annual Conference and Exhibition. Seattle, USA, 14-17 June, 2015.

Lozano, R., Merrill, M.Y., Sammalisto, K., Ceulemans, K. and Lozano, F. “Connecting Competences and Pedagogical Approaches for Sustainable Development in Higher Education: A Literature Review and Framework Proposal”, Sustainability, 2017, 9(10).

Male, S., King, R., and Hargreaves, D. "Drivers and barriers to industry engaging in engineering education, In $12^{\text {th }}$ International CDIO Conference, 12-16 June 2016, Turku, Finland.

McAuliffe, M.B., Hargreaves, D., Winter, A.J., and Chadwick, G., "Does pedagogy still rule?", Australasian Journal of Engineering Education, 2009, 15(1).

Mukhtar, N, N., Saud, M.S., Kamin, Y., Al-Rahmi, W.M., Kosnin, A., and Yahaya, N., "Environmental Sustainability Competency Framework for Polytechnics Engineering Programmes", in IEEE Access, DOI: 10.1109/ACCESS.2019.2936632

Mulder, K., Desha, C., and Hargroves, K., "Sustainable development as a meta-context for engineering education", in Journal of Sustainable Development of Energy, Water and Environment Systems, 2013, 1(4), pp 304-310.

Rose, G., Ryan, K., and Desha, C., "Implementing a holistic process for embedding sustainability: A case study in first-year engineering, Monash University, Australia", Journal of Cleaner Production, 2015, 106, pp 229-238.

Rosén, A., Edström, K., Grøm, A., Gumaelius, L, Hussmann, P.M., Högfeldt, A-K., Karvinen, M., Keskinen, M., Wedel, M.N, Lundqvist, U., Lyng, R., Malmqvist, J., Nygaard, M., Vigild, M., and Astrup, T.F., "Mapping the CDIO Syllabus to the UNESCO key competencies for sustainability", in Proceedings of the 15th International CDIO Conference, Aarhus University, Denmark, 2019.

Rowe, D., "Education for a Sustainable Future", in Policy Forum, Science, 2007, Vol 317, pp 323324.

Rowe, D., Achieving Sustainability: Vision, Principles and Practices, First edition, Macmillan Reference, USA, 2014.

Rowe, D., and Hiser, K. "Chapter 21: Higher education for sustainable development in the community and through partnerships", in Barth, M., Michelsen, G., Rieckmann, M., and Thomas, I. (Eds) Routledge Handbook of Higher Education for Sustainable Devleopment, Routledge, London, 2015.

Rowe, D., and Johnston, L. Chapter 4: Learning Outcomes: An International Comparison of Countries and Declarations", in Johnston, L. (Ed) Higher Education for Sustainability: Cases, Challenges, and Opportunities from Across the Curriculum, 2013, pp 45-60.

Segalas, J., Ferrer-Balas, D., Svanstrom, M., Lundqvist, U., and Mulder, K.F., "What has to be learnt for sustainability? A comparison of bachelor engineering education competencies at three European universities", in Sustainability Science, 2009, 4(1), pp 17-27.

Svanström, M., Lozano-García, F., and Rowe, D., "Learning outcomes for sustainable development in higher education", International Journal of Sustainability in Higher Education, 2008, 9(3), pp 
339-351.

Taylor, E., "Capacity Building for Sustainable Development through the International Engineering Alliance Accords", presentation to the International Engineering Alliance's CAST International Forum on Engineering Capacity, November 2018, Beijing, China.

Fridley, K., Back, W.E. and Williamson D.G. "The ASCE BOK, ABET Accreditation Criteria, and NCEES FE Exam - Are They Appropriately Aligned?", in proceedings of the $123^{\text {rd }}$ ASCE Annual Coference, 26-29 June, New Orleans.

The American Society of Civil Engineers, "Canon 8: Codifying Diversity as Ethics", 2018, Paper 21970.

Thürer, M., Tomašević, I., Stevenson, M., Qu, T., and Huisingh, D., "A Systematic Review of the Literature on Integrating Sustainability into Engineering Curricula" in Journal of Cleaner Production, 2018, 181, pp 608-617.

United Nations., Transforming our world: the 2030 Agenda for Sustainable Development, UN General Assembly, 21 October 2015, A/RES/70/1.

Weatherton, Y.P., Sattler, M., Mattingly, S., Chen, V., Rogers, K.J. and Dennis, B., "Multipronged Approach for Incorporating Sustainability into an Undergraduate Civil Engineering Curriculum", in Journal of Professional Issues in Engineering Education and Practice, 2015, 141(2): C5014003.

Wiek., A, Withycombe., L, and Redman, CL., "Key competencies in sustainability: a reference framework for academic program development”, Sustainability Science. 2011, 6(2), pp 203-218.

World Federation of Engineering Organisations, "Model Code of Practice for Sustainable Development and Environmental Stewardship Interpretive Guide", Committee on Engineering and the Environment, 2013.

World Federation of Engineering Organisations, WFEO Engineering 2030: A Plan to advance the achievement of the UN Sustainable Development Goals through engineering. A collaborative project with the UNESCO Division of Science Policy and Capacity Building - Natural Sciences Sector. Progress Report No.1, October 2018.

\section{REFERENCED WEBSITES}

Accreditation Board for Engineering and Technology

https://www.abet.org/accreditation/accreditation-criteria/criteria-for-accrediting-engineeringprograms-2019-2020/\#GC3

Alliance for Sustainability Leadership in Education (EAUC), https://www.eauc.org.uk/

Association for the Advancement of Sustainability in Higher Education (AASHE), https://www.aashe.org/partners/heasc/members/

Beyond Doom and Gloom: Engage in Climate Solutions initiative, http://www.aashe.org/climatesolutions/

Centre for Sustainable Engineering, http://csengin.syr.edu/

Center for Sustainable Engineering ( http://www.csengin.org)

Committee on Engineering Education (CEIE), https://www.wfeo.org/committee-engineering-and-theenvironment/

Committee on Engineering and the Environment, https://www.wfeo.org/committee-engineering-andthe-environment/

Disciplinary Associations' Network for Sustainability, http://www.aashe.org/dans/

Engineers Australia., "Meet the President-elect of WFEO", https://www.engineersaustralia.org.au/News/meet-president-elect-wfeo

Facing the Future, www.facingthefuture.org/

Global Alliance, https://www.eauc.org.uk/global alliance/

Higher Education Academy - Education for Sustainable Development Knowledge Hub, https:/www.heacademy.ac.uk/individuals/strategic-priorities/education-sustainable-development/ 
Higher Education Associations Sustainability Consortium, http://www.aashe.org/heasc/

2018 International Forum on Engineering Capacity, https://www.wfeo.org/event/international-forumon-engineering-capacity/

International Energy Agency, https://www.ieagreements.org

Principles for Responsible Management Education (PRME), http://www.unprme.org/aboutprme/index.php/

Projects That Matter platform, http://www.projectsthatmatter.org/

ProSPER.Net, http://prospernet.ias.unu.edu/

SDG Accord, https://www.sdgaccord.org/

Sulitest, http://www.sulitest.org/

Sustainability Education and Economic Development Center, http://www.theseedcenter.org/

Sustainability Improves Student Learning, https://serc.carleton.edu/sisl/pedagogies.html, https://serc.carleton.edu/sisl/empowering_stud.html.

The Green Office Movement. http://rootability.com/sustainable-campus-and-green-universitynetworks-and-initaitives/

US Partnership on Education for Sustainable Development, https://uspartnership.org/

UN Environment, Green University Networks, https://www.unenvironment.org/exploretopics/education-environment/why-does-education-and-environment-matter/green-university/

United Nations Higher Education Sustainability Initiative (HESI), https://sustainabledevelopment.un.org/sdinaction/hesi/

World Engineering Day for Sustainable Development, https://www.wfeo.org/world-engineering-dayfor-sustainable-development/

https://www.abet.org/accreditation/accreditation-criteria/criteria-for-accrediting-engineeringprograms-2018-2019/\#GC3 